\title{
FORUM
}

\section{Eradicating mammals on New Zealand island reserves: what is left to do?}

\author{
John P. Parkes ${ }^{1 *}$, Andrea E. Byrom ${ }^{2}$ and Kerri-Anne Edge ${ }^{3}$ \\ ${ }^{1}$ Kurahaupo Consulting, 2 Ashdale Lane, Christchurch 8052, New Zealand \\ ${ }^{2}$ Landcare Research, PO Box 69040, Lincoln 7640, New Zealand \\ ${ }^{3}$ Edge-Effect, 48 Bligh St, Te Anau, New Zealand \\ *Author for correspondence (Email: john.parkes1080@gmail.com)
}

Published online: 5 April 2017

\begin{abstract}
In 2016, the New Zealand Government announced a policy to rid the country of key introduced predators (possums (Trichosurus vulpecula), ship rats (Rattus rattus), Norway rats ( $R$. norvegicus) and mustelids (Mustela spp.)) by 2050. An interim goal under this policy is to remove all mammalian predators (the key species as well as mice (Mus musculus), kiore (R. exulans), cats (Felis catus), pigs (Sus scrofa) and hedgehogs (Erinaceus europaeus)) from island nature reserves by 2025. We identify the New Zealand islands over one hectare managed as reserves by the Department of Conservation (DOC) that have mammalian predators that can be eradicated. There are over 850 islands, islets, stacks and vegetated rocks in the New Zealand archipelago. We exclude islands in lakes and rivers and those smaller than one hectare, which leaves 616 islands, less than half of which are under some form of reserve status (286 islands entirely managed by DOC and 13 under mixed tenures but with some reserve land). One or more mammalian predators are known to occur on 48 of these islands, with the Government's 2050 target species on 42 islands and other predators (in the absence of the target species) on six islands. The Government's 2025 goal nominates one class of reserve, nature reserves. Of the 48 islands, just four islands are classed as nature reserves - two (Mauitaha and Araara Islands) with protected kiore in the Hen and Chickens group and two in the Auckland Islands group (Auckland with mice, cats and pigs; and Masked with mice and cats) - i.e. none with the key species of the wider 2050 goal. Therefore, we consider other reserve classes but place more or less strict risks of reinvasion, as indexed by known swimming ranges of the predators, to judge the feasibility of eradication. Relaxing the reserve class of the island, but not our selection of swimming ranges, results in 15 candidate islands where all mammalian predators present could be eradicated for the 2025 interim goal. Decisions on which islands to select for the programme need to consider costs and other constraints to eradicate different combinations of predators, and whether the island and its predators provide templates for the wider vision of a predator-free New Zealand, i.e. whether any of the key 2050 predators are present, the size of the island, and/or the presence of human inhabitants that complicate the predators to be targeted or constrain the use of some control methods.
\end{abstract}

Keywords: costs; eradication; invasion risks; predators; reserves

\section{Introduction}

In July 2016, the New Zealand Government announced an ambitious goal, PredatorFree New Zealand (PFNZ2050), of eradicating key invasive mammalian predators from the country by 2050 with seed funding of $\$ 7$ million $^{1}$ per year from central government aimed at incentivising massive investment in funding and support from the nation (Cabinet 2016). Intermediate goal three of the initiative states that 'by 2025 we will have eradicated all mammalian predators from New Zealand's island nature reserves' (Cabinet 2016). We discuss what this intention means by defining what might be meant by 'nature reserves', 'eradicate', and 'mammalian predators' to assess which islands meet narrow or broad criteria. We then estimate the costs and note some of the constraints to complete the eradications on all or some of the islands using currently available technologies, and thereby explore the implications of this interim objective for the eventual PFNZ2050 vision.

\section{Methods - definitions for selection criteria}

\section{New Zealand's islands}

New Zealand has more than 850 islands, islets and stacks. We apply a sequence of criteria to select islands that meet the Government's PFNZ2050 and 2025 goals (Fig. 1). Firstly, we do not consider islands in lakes and rivers and have used a size of one hectare as a cut-off, which resulted in 616 potential candidate islands. We exclude small islands, stacks and rocky islets because most (98\%) are adjacent to a larger island and therefore would be part of any eradication project on that island. The data on the status of New Zealand's islands are partially recorded in databases on eradication efforts (e.g. Clout \& Russell 2006; Towns et al. 2012; DIISE at www. islandconservation.org) and more generally in a database maintained by JP and updated for this paper by the authors and the people acknowledged. Information on their tenure is from the literature, online at www.doc.govt.nz/mapviewer or www.Maorilandonline.govt.nz.

\footnotetext{
${ }^{1}$ All costs are in 2016 New Zealand dollars.
} 


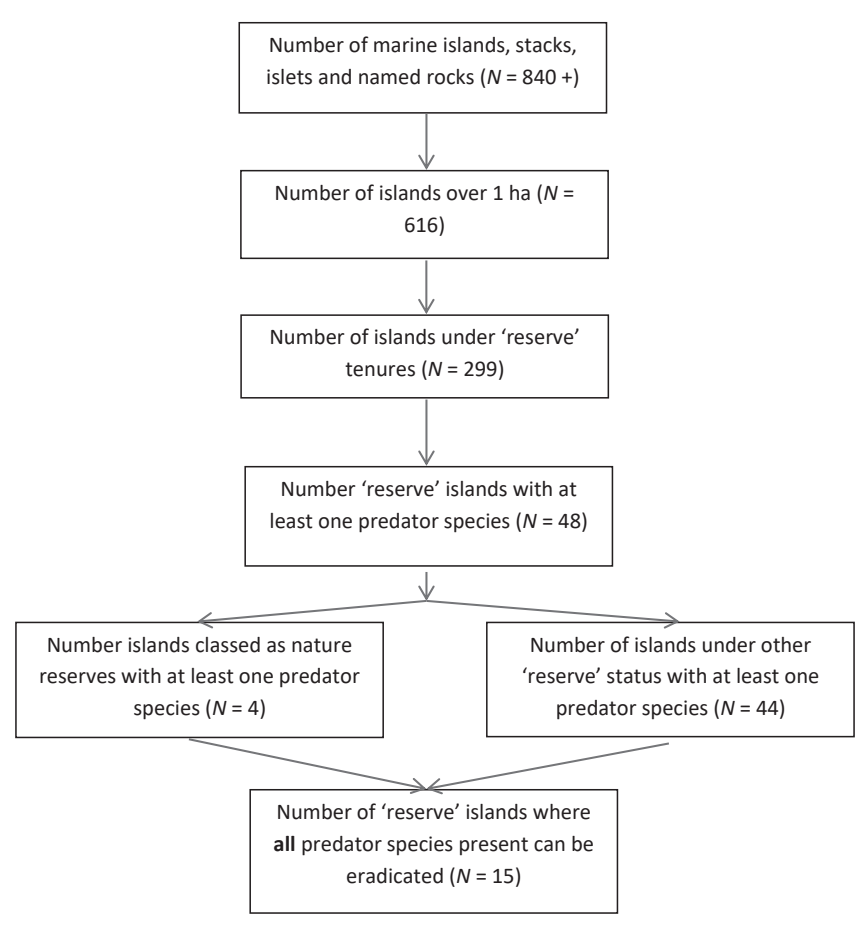

Figure 1. Selection criteria to sort New Zealand island reserves for predator eradication.

\section{Reserves \\ A second criterion to narrow the selection of candidate islands for action under the Government's 2025 policy from among the 616 islands is to focus on islands defined as reserves under the Reserves Act 1977, the National Park Act 1980 or the Conservation Act 1987. A few islands, which we do not consider, are managed as reserves or to protect biodiversity by local governments (e.g. Limestone Island in Whangarei Harbour) or private landowners (e.g. White Island) including Māori-owned islands (e.g. many of the tìtì islands off Stewart Island or the Sugarloaf Islands at New Plymouth).}

\section{Target species}

The third selection criterion is to consider islands with predators, either any mammalian predator or just those named as key targets in the PFNZ2050 initiative. Mammals named in the Cabinet paper (Cabinet 2016) were possums (Trichosurus vulpecula), stoats (Mustela erminea) and rats (Rattus spp.). Department of Conservation(DOC) background papers include the other mustelids, ferrets (Mustela furo) and weasels (M. nivalis) as key predators, but exclude kiore (R. exulans). The criterion could be widened as these are not the only mammalian predators on New Zealand islands, with mice (Mus musculus), cats (Felis catus), pigs (Sus scrofa) and hedgehogs (Erinaceus europaeus) being present on some islands, some with and some without the key predators.

\section{Eradication}

A fourth criterion to narrow the selection of candidate islands is to only consider those islands where eradication of any or all of the mammalian predators present is feasible. There are many reasons why eradication may not be feasible (Parkes \& Panetta 2009) but for this paper we consider only the risk that a target species already present on the island will be able to swim from a source area after resident animals are removed.
Risks of reinvasion by rafting, stowing away on vessels or by deliberate liberation by people are not considered.

All of the predator species under consideration can swim, some much better and more frequently than others. Stoats and Norway rats ( $R$. norvegicus) readily swim to islands thousands of metres from source populations, ship rats (R. rattus) to islands hundreds of metres from sources, while the other species are more reluctant swimmers and rarely swim to islands more than tens of metres from sources. We have data on how long or how far individuals can swim under experimental conditions (e.g. King et al. 2014) or when cast into the ocean (e.g. Whitaker 1974), and therefore can extrapolate how far they might swim under natural conditions to reach an island. Second, we have empirical data on actual distances animals have swum to reach islands. The distances and frequencies depend on the different species' swimming ability, nearest source population(s) and their population densities, and water temperature and currents (e.g. see Russell et al. 2008 and references therein).

Among the predator species, stoats are the best swimmers. Based on data from small islands off Abel Tasman National Park, Taylor and Tilley (1984) noted that all islands closer than $800 \mathrm{~m}$ to the mainland suffered from regular invasions by stoats, and only islands over $1200 \mathrm{~m}$ from source populations were safe. Genetic analysis of stoats on Secretary Island showed that animals were a mix of residents and recent immigrants that had swum to the island across at least $630 \mathrm{~m}$ via stepping stone islands (McMurtrie et al. 2011). Immigration events were low in most years ( $0-2$ animals), but at least eight stoats were known to have swum to the island in 2007 (Veale et al. 2013). In 2009, a single pregnant female stoat apparently swam the $5285 \mathrm{~m}$ (shortest gap $4517 \mathrm{~m}$ ) to Kapiti Island - likely a rare extreme event as stoats had never previously been recorded on the island. In 2010, a stoat was found on Rangitoto Island $3300 \mathrm{~m}$ (shortest gap $2476 \mathrm{~m}$ ) from its likely source population on the North Shore (King et al. 2014) - a more frequent invasion event given the resident stoats on the island had limited ongoing mixing with the mainland stoats (Veale et al. 2012). Both incursions were detected and the animals removed (Prada et al. 2014). It suggests there are risks from stoats to islands further offshore than originally supposed by Taylor and Tilley (1984). It is likely that the greater the distance the lower the risk that a stoat (or any animal) will swim to an island. We know, for example, that an incursion of stoats was detected on 309 ha Maud Island (900 m from South Island source populations) in 1982 and removed (Crouchley 1994) and subsequently three stoats and a weasel reached the island between 1990 and 2003 without establishing more than the first generation before being removed (Crouchley 1994; Parkes \& Murphy 2003).

Russell et al. (2008) recorded water gaps of $500 \mathrm{~m}$ and $387 \mathrm{~m}$ across which ship rats invaded Motutapere and Tawhitinui Islands, respectively, while Norway rats can swim across $1000 \mathrm{~m}$ of water and possibly up to $2200 \mathrm{~m}$ under ideal conditions (Moors 1985; Clout \& Russell 2006). Kiore are poor swimmers, but did colonise Lizard Island in the mid-1970s presumably by swimming across the $42 \mathrm{~m}$ (widest water gap) from Burgess Island in the Mokohinau Group (McCallum 1986). Possums, cats, pigs, ferrets and perhaps mice are also reluctant swimmers and when they do it seems to be as a result of 'accidents' or disturbance rather than a natural part of their dispersal behaviours. Almost all island invasions of these latter five species appear to require human assistance to reach islands more than a few metres from source populations (King 2005).

A risk-averse approach to deciding on candidate islands 
would make use of the known maximum distances reported for each species. A less cautious approach would support decisions on this criterion based on observed frequencies of invasions - if enough data were available. For our purposes, we set minimum swimming distance criteria of $2500 \mathrm{~m}$ for stoats, $1500 \mathrm{~m}$ for Norway rats, $500 \mathrm{~m}$ for ship rats, and 100 $\mathrm{m}$ for all other species.

\section{Results and discussion}

\section{Candidate islands}

The past and present status of mammals on 616 offshore islands over one ha in the New Zealand archipelago is summarised in Table 1.

Of the 616 islands in Table 1, 49\% are under some form of legal reserve status in whole $(n=286)$ or in part $(n=13)$. These are usually within the public conservation estate and managed by DOC. Their legal status varies from highly protected with restricted access in nature reserves $(n=129$, mostly in outlying island groups), to highly protected but with public access in national parks $(n=100$, mostly islands in Fiordland), to scenic reserves for both public enjoyment and biodiversity protection $(\mathrm{n}=30$, mostly islands close to the main islands), to recreation reserves with more focus on public use $(n=14)$ and a variety of special reserves such as scientific reserves, historic reserves, wildlife management areas, conservation parks, and stewardship conservation areas $(\mathrm{n}=13)-$ as well as the 13 islands with some DOC and some private or Māori tenures.

Filtering for the presence of one or more mammalian predator species reduces the 299 islands managed, at least in part, by DOC under different reserve tenures to 48 islands (Table 2). Therefore, these 48 islands are the candidates for consideration for predator removal under the island size and a broad reserve criterion. They are listed according to their mammal status (only rodents, rodents plus other key predators, or only other predators), which has implications for the control methods required for eradication and for associated costs. We note that most islands in Fiordland National Park have red deer (Cervus elaphus) present from time to time, while stoats and ship rats may also come (during beech mast events) and go (or at least be undetectable) when this food supply is absent.

We now apply the other criteria, either strictly or liberally and in different orders to sort the islands in Table 2. Strict criteria would be to focus on the key predators named in the PFNZ2050 policy (rats, stoats and possums) occurring on the islands classed as nature reserves that are outside our maximum known swimming distances. However, these restrictions are not helpful for the interim 2025 goals because they reduce the candidate islands to only two - Mauitaha Island and its adjacent islet Araara in the Hen and Chickens group - both nature reserves with kiore, however, the kiore are protected as part of an agreement with Ngatiwai. Therefore, one or more of the criteria need to be relaxed to provide a sensible list of candidate islands.

Under the 'all mammalian predators' policy of the 2025 interim goal but with narrow nature reserve and swimming distance criteria we add only two islands - Auckland Island with mice, cats and pigs and its adjacent islet Masked Island with mice and cats. If we relax the tenure criterion to include all reserves and consider all mammalian predators, but retain our swimming distance rule, 15 islands (including the four from the Hen and Chickens and Auckland Islands groups) are candidates (Table 3 ). The 25 national park islands with predators are not candidates under our swimming distance criterion, although extirpation of the predators with ongoing management of immigrants is an alternative strategy to eradication and is being attempted for many of these islands (e.g. Anderson et al. 2016).

The 15 candidate islands include six managed entirely by DOC and seven of mixed tenures (Table 3 ). The mixed tenure islands are inhabited and for two (Stewart and Great Barrier) any attempt to eradicate the target species would need to include the adjacent islands, which are usually within swimming distance of the main island.

\section{Costs}

The presence of rodents on most candidate islands sets baseline costs for eradication projects. The implementation or operational $\operatorname{cost}^{2}$ to aerially sow brodifacoum baits (Broome et al. 2014) against rodents averaged c. $\$ 300 \mathrm{ha}^{-1}$ for New Zealand projects on uninhabited islands (e.g. for Campbell Island see McClelland (2001); for Rangitoto-Motutapu Islands see Griffiths et al. (2015); and for Raoul, Little Barrier and Hen Islands see Holmes et al. (2016) and references therein). However, costs on inhabited or farmed islands can be much higher as a consequence of having to work around people and livestock, e.g. $\$ 800 \mathrm{ha}^{-1}$ for Great Mercury Island and $\$ 7000 \mathrm{ha}^{-1}$ for Lord Howe Island (K. Broome, pers. comm.). At $\$ 800 \mathrm{ha}^{-1}$ the costs to aerially bait the four large, inhabited

\footnotetext{
${ }^{2}$ Reported costs are difficult to compare as full overhead and salary costs are not always reported, and aerial baiting methods (sowing rates and number of sowings) and logistic costs for remote islands versus closer ones are highly variable.
}

Table 1. Status of introduced mammals, both predators and herbivores, on 616 islands over one ha in New Zealand.

\begin{tabular}{lccc}
\hline Mammal status & $\begin{array}{c}\text { No. islands/ DOC } \\
\text { reserves }\end{array}$ & $\begin{array}{c}\text { Total area } \\
\text { (ha) }\end{array}$ & $\begin{array}{c}\text { Mean size } \\
\text { (ha) 95\% CL }\end{array}$ \\
\hline Never had mammals & $148 / 90$ & 1899 & $13 \pm 6$ \\
All died out naturally & $6 / 6$ & 10240 & Disappointment (375) \\
All removed/eradicated & $143 / 94$ & 50840 & $1707 \pm 3212$ \\
Total mammal-free & $\mathbf{2 9 7 / 1 9 1}$ & $\mathbf{6 2 ~ 9 7 9}$ & $356 \pm 205$ \\
Some eradicated, some remain & $33 / 9$ & 250854 & $\mathbf{2 1 1} \pm \mathbf{1 2 1}$ Campbell (11 331) \\
Present - none eradicated & $177 / 78$ & 174199 & $984 \pm 1054$ \\
Total with mammals & $\mathbf{2 1 0 / 8 6}$ & $\mathbf{4 2 5} \mathbf{0 2 3}$ & $\mathbf{2 0 2 3} \pm \mathbf{1 9 0 3}$ \\
Unknown status & $109 / 22$ & 1375 & $13 \pm 8$
\end{tabular}


Table 2. Presence of mammalian predators on islands over one ha where all or some of the island is managed by DOC under 'reserve' tenures. $\mathrm{NP}=$ national park, $\mathrm{NR}=$ nature reserve, $\mathrm{RR}=$ recreation reserve, $\mathrm{SR}=$ scenic reserve, $\mathrm{LHR}=$ lighthouse reserve, Mixed $=$ some DOC reserve amid private land.

\begin{tabular}{|c|c|c|c|c|c|c|c|}
\hline Island & Location & $\begin{array}{l}\text { Area } \\
\text { (ha) }\end{array}$ & $\begin{array}{l}\text { Distance } \\
(\mathrm{m})\end{array}$ & Status & $\begin{array}{l}\text { Target } \\
\text { predators }\end{array}$ & $\begin{array}{l}\text { Other } \\
\text { predators }\end{array}$ & Notes \\
\hline \multicolumn{8}{|c|}{ Only rodents present as of 2016 : } \\
\hline Motukawanui & $3458 \mathrm{~S} 173$ 58E & 352 & 2350 & Mixed & Kiore & & Possibly stoats? \\
\hline Rakitu & 36 08S $17530 \mathrm{E}$ & 312 & 2500 & SR & Ship rat & & Kiore presence unclear \\
\hline Quail & 43 38S 172 42E & 80 & 250 & $\mathrm{RR}$ & & Mice & Many others eradicated \\
\hline West Rugged & $4642 \mathrm{~S} 16742 \mathrm{E}$ & 30 & 200 & NP & Rats & & Stewart Island unit \\
\hline Mauitaha & 35 54S $17441 \mathrm{E}$ & 23 & 10000 & NR & Kiore & & Kiore protected \\
\hline Tawhitinui & $4102 \mathrm{~S} 17348 \mathrm{E}$ & 22 & 393 & SR & Ship rat & & $\begin{array}{l}\text { Stoats and deer swim on } \\
\text { and off }\end{array}$ \\
\hline Rimariki & $3526 \mathrm{~S} 17426 \mathrm{E}$ & 16 & 400 & SR & Norway rat & & Re-invaded \\
\hline Tommy & $4657 \mathrm{~S} 16807 \mathrm{E}$ & 15 & 250 & NP & Rats & & Stewart Island unit \\
\hline Quarantine & 45 49S $17038 \mathrm{E}$ & 14 & 200 & $\mathrm{RR}$ & Ship rat & & Re-invaded \\
\hline Goat & $4657 \mathrm{~S} 16808 \mathrm{E}$ & 12 & 400 & NP & Ship rat, Norway rat & & Stewart Island unit \\
\hline East Rugged & 46 42S $16743 \mathrm{E}$ & 10 & 200 & NP & Rats & & Stewart Island unit \\
\hline Crayfish & $4657 \mathrm{~S} 16807 \mathrm{E}$ & 10 & 250 & NP & $\begin{array}{l}\text { Ship rat, Norway rat, } \\
\text { kiore }\end{array}$ & & Stewart Island unit \\
\hline Groper & $4657 \mathrm{~S} 16808 \mathrm{E}$ & 8 & 400 & NP & Ship rat, Norway rat & & Stewart Island unit \\
\hline Awaiti & 41 03S 173 49E & 7 & 350 & SR & Ship rat & & Re-invaded \\
\hline Araara & 35 53S $17442 \mathrm{E}$ & 2 & 10800 & NR & Kiore & & Kiore protected \\
\hline Ngawhiti & 40 48S 172 54E & 2 & 250 & NP & Ship rat & & Possibly stoats \\
\hline Motu & $4048 \mathrm{~S} 17254 \mathrm{E}$ & 2 & 150 & NP & Ship rat & & Possibly stoats \\
\hline Refuge & $4656 \mathrm{~S} 16807 \mathrm{E}$ & 2 & 200 & NP & Rats & & Stewart Island unit \\
\hline Doughboy Bay & $4702 \mathrm{~S} 16741 \mathrm{E}$ & 2 & 20 & NP & $\begin{array}{l}\text { Ship rat, Norway rat, } \\
\text { kiore }\end{array}$ & & Stewart Island unit \\
\hline \multicolumn{8}{|c|}{ Rodents plus other predators present as of 2016: } \\
\hline Stewart & 47 00S $16750 \mathrm{E}$ & 168540 & 28000 & Mixed & $\begin{array}{l}\text { Kiore, ship rat, Norway } \\
\text { rat, possum }\end{array}$ & Cat, hedgehog & $\begin{array}{l}\text { Inhabited, red and whitetail } \\
\text { deer }\end{array}$ \\
\hline Chatham & 44 03S $17628 \mathrm{~W}$ & 90650 & 645000 & Mixed & $\begin{array}{l}\text { Kiore, ship rat, Norway } \\
\text { rat, possum }\end{array}$ & Cat, pig & $\begin{array}{l}\text { Inhabited, red deer, sheep, } \\
\text { cattle }\end{array}$ \\
\hline Auckland & $5054 \mathrm{~S} 16606 \mathrm{E}$ & 45975 & 370000 & NR & & Mice, cat, pig & \\
\hline Great Barrier & $3613 \mathrm{~S} 17524 \mathrm{E}$ & 27720 & 16200 & Mixed & Ship rat & Mice, cat, pig & Inhabited, rabbit \\
\hline Resolution & 45 40S $16637 \mathrm{E}$ & 20882 & 520 & NP & Stoat & Mice & $\begin{array}{l}\text { Stoats being removed, red } \\
\text { deer }\end{array}$ \\
\hline D’Urville & $4050 \mathrm{~S} 17351 \mathrm{E}$ & 16652 & 500 & Mixed & Kiore, stoat & $\begin{array}{l}\text { Mice, cat, } \\
\text { hedgehog, pig }\end{array}$ & $\begin{array}{l}\text { Inhabited, red and fallow } \\
\text { deer }\end{array}$ \\
\hline Waiheke & 36 47S 175 07E & 9220 & 4600 & Mixed & Norway rat, stoat & $\begin{array}{l}\text { Mice, cat, } \\
\text { hedgehog, ferret, } \\
\text { pig }\end{array}$ & Inhabited \\
\hline Arapawa & $4111 \mathrm{~S} 17419 \mathrm{E}$ & 7604 & 600 & Mixed & Kiore, ship rat, stoat & Mice, cat, pig & Inhabited, red deer, goats \\
\hline Pitt & $4430 \mathrm{~S} 17615 \mathrm{~W}$ & 6203 & 21000 & Mixed & & Mice, cat, pig & Inhabited, sheep, cattle \\
\hline Kawau & $3625 \mathrm{~S} 17451 \mathrm{E}$ & 2032 & 1500 & Mixed & $\begin{array}{l}\text { Ship rat, stoat, ferret, } \\
\text { possum }\end{array}$ & Cat & Inhabited, wallabies \\
\hline Long & 45 46S $16642 \mathrm{E}$ & 1899 & 550 & NP & Ship rat, stoat & Mice & $\begin{array}{l}\text { Stoats being removed, red } \\
\text { deer }\end{array}$ \\
\hline Cooper & 45 44S $16650 \mathrm{E}$ & 1770 & 180 & NP & Rat, stoat & Mice & \\
\hline Great & 45 59S $16634 \mathrm{E}$ & 740 & 271 & NP & Rat, stoat & Mice & $\begin{array}{l}\text { Stoats being removed, red } \\
\text { deer }\end{array}$ \\
\hline Harbour & $4535 \mathrm{~S} 16646 \mathrm{E}$ & 51 & 146 & NP & Rat, stoat & & Red deer \\
\hline Johns West & 45 34S $16648 \mathrm{E}$ & 45 & 157 & NP & Rat, stoat & & Red deer \\
\hline Parrot & 45 43S $16632 \mathrm{E}$ & 40 & 800 & NP & Stoat & Mice & $\begin{array}{l}\text { Stoats being removed, red } \\
\text { deer }\end{array}$ \\
\hline Tarakaipa & $4104 \mathrm{~S} 17348 \mathrm{E}$ & 35 & 850 & SR & & Mice, pig & \\
\hline Mahurangi & 36 50S 175 49E & 23 & 300 & $\mathrm{RR}$ & $\begin{array}{l}\text { Ship rat, Norway rat, } \\
\text { stoat }\end{array}$ & & \\
\hline Curlew & 45 47S $16636 \mathrm{E}$ & 14 & 682 & NP & Ship rat, stoat & Mice? & Stoats being removed \\
\hline Cormorant & 45 41S $16633 \mathrm{E}$ & 14 & 254 & NP & Rat, stoat & Mice & Stoats being removed \\
\hline Masked & $5050 \mathrm{~S} 16602 \mathrm{E}$ & 4 & 70 & NR & & Mice, cat & \\
\hline \multicolumn{8}{|c|}{ Predators present but no rodents recorded as of 2016: } \\
\hline Rakino & $3643 \mathrm{~S} 17457 \mathrm{E}$ & 150 & 1500 & Mixed & & Cat & \\
\hline Elizabeth & $4525 \mathrm{~S} 16707 \mathrm{E}$ & 66 & 157 & NP & Stoat & & \\
\hline Motutapere & $3647 \mathrm{~S} 17526 \mathrm{E}$ & 45 & 500 & SR & Stoat & & \\
\hline Entry & $4536 \mathrm{~S} 16642 \mathrm{E}$ & 38 & 1003 & NP & Stoat & & Stoats being removed \\
\hline Oke & 45 38S $16651 \mathrm{E}$ & 35 & 304 & NP & Stoat & & \\
\hline Fixed & 45 44S $16635 \mathrm{E}$ & 22 & 134 & NP & Stoat & & Stoats being removed \\
\hline Fergusson & 45 24S $16706 \mathrm{E}$ & 12 & 571 & NP & Stoat & & \\
\hline Heron & $4547 \mathrm{~S} 16635 \mathrm{E}$ & 6 & 221 & NP & Stoat & & \\
\hline
\end{tabular}


Table 3. List of candidate islands for the 2025 interim goal of eradication based on all mammalian predators currently present, all reserve tenures but outside swimming range of any species currently present.

\begin{tabular}{|c|c|c|c|c|}
\hline Island & Area (ha) & Tenure & Predators present & Possible exclusion factors \\
\hline \multicolumn{5}{|c|}{ Entire island managed by DOC } \\
\hline Auckland & 45975 & NR & Mice, cats, pigs & Cost \\
\hline Rakitu & 312 & SR & Ship rat, kiore? & Already planned \\
\hline Quail & 80 & $\mathrm{RR}$ & Mice & With range of species already removed, managed by Trust \\
\hline Tarakaipa & 35 & SR & Mice, pigs & \\
\hline Mauitaha & 26 & NR & Kiore & Kiore protected \\
\hline Awaiti & 7 & SR & Ship rats & Reinvaded and within range of stoats \\
\hline Masked & 4 & NR & Mice, cats & Adjacent to Auckland Island \\
\hline Araara & 2 & NR & Kiore & Kiore protected \\
\hline \multicolumn{5}{|c|}{ Only part of island managed by DOC } \\
\hline Stewart & 168540 & & $\begin{array}{l}\text { Kiore, ship rats, Norway rats, } \\
\text { possums, cats }\end{array}$ & Need to include 105 adjacent islands \\
\hline Chatham & 90650 & & $\begin{array}{l}\text { Kiore, ship rats, Norway rats, } \\
\text { mice, possums, cats, pigs }\end{array}$ & Pigs valued asset by inhabitants \\
\hline Great Barrier & 28510 & & $\begin{array}{l}\text { Kiore, ship rats, cats, pigs } \\
\text { by inhabitants }\end{array}$ & Need to include 32 adjacent islands. Pigs valued asset \\
\hline Waiheke & 9459 & & $\begin{array}{l}\text { Norway rats, mice, stoats, } \\
\text { ferrets, hedgehogs, pigs, cats }\end{array}$ & $\begin{array}{l}\text { Mustelid eradication being considered for part of } \\
\text { the island }\end{array}$ \\
\hline Pitt & 6203 & & Mice, cats, pigs & Pigs valued by inhabitants \\
\hline Motukawanui & 355 & & Kiore & Already planned \\
\hline Rakino & 150 & & Cats & Inhabited \\
\hline
\end{tabular}

islands in Table 3 would approach $\$ 250$ million. The costs to eradicate all other non-rodent predators are case-specific. Standard aerial baiting for rodents kills a high proportion of non-rodent predators by primary and secondary poisoning, but in few cases is this $100 \%$. In fact only once has it occurred, on Tuhua Island when baiting rats killed all the cats (Campbell et al. 2011). The cost to remove survivors is variable, and of course depends on the number of non-rodent species present, but is usually high. For example, on Rangitoto-Motutapu Islands, the cost to remove and validate success for the four non-rodent species (stoats, cats, hedgehogs and rabbits) was about the same as to remove the rodents (Griffiths et al. 2015) - with sobering extrapolations for attempting the whole of New Zealand with current methods (Parkes et al. 2017).

Eradicating cats, stoats, pigs and possums requires different strategies and tools for each species, although of course where they are sympatric there are some costs shared between the species if they are managed simultaneously. Eradicating feral pigs from 25000 ha Santa Cruz Island in California in 2005/06 cost c. NZ\$5.5 million in direct operating costs (plus costs of fencing, planning, audit and litigation) (Morrison 2007), so extrapolating to the eight islands with pigs in our wider list would cost c. NZ\$83 million, assuming the islands' inhabitants would allow pigs to be eradicated.

Campbell et al. (2011) reported costs to eradicate established populations of cats from eight islands that varied from c. $\$ 80 \mathrm{ha}^{-1}$ to c. $\$ 600 \mathrm{ha}^{-1}$. The cost on Macquarie Island between 1998 and 2002 were c. $\$ 300$ ha $^{-1}$ for 6298 field days (Robinson \& Copson 2014). Thus, to target the feral cats on the islands listed in Table 2 would cost $\$ 92$ million - probably less if the rodents were treated before surviving cats were removed.

The costs to remove possums from Kapiti Island (1965 ha) during the 1980s using ground-based control methods was $\$ 839$ ha $^{-1}$ (Cowan 1992). This was done before the rodents were eradicated in 1996 (Empson \& Miskelly 1999), so for our candidate islands in Table 3 with both rodents and possums (Stewart and Chatham Islands) costs for the initial reduction phase of cat eradication would be subsumed in the costs of aerial baiting of the rodents.

Stoats are only present on one island (Waiheke Island) outside our cut-off for swimming range, and a current community initiative is considering whether eradication of stoats and ferrets is possible (Ritchie \& Cullum 2016, unpubl. Whakanewha to Otetangi mustelid control pilot study). All other islands with stoats, including those being removed in the current campaigns on Secretary and Resolution Islands (Clayton et al. 2011; Anderson et al. 2016), are likely to be reinvaded while stoats are present (especially when at peak densities) on the adjacent mainland, so goals of extirpation and removal of immigrants rather than eradication are more appropriate.

\section{Other considerations}

Some of the islands are isolated and thus stand-alone with respect to eradication projects, but Stewart and Great Barrier Islands have about 105 and 32 adjacent islands, respectively, that would need to be cleared of predators to succeed with predator removal on the main islands. Some of these adjacent islands have never had mammals, some have been cleared and a few (e.g. Rakitu) are far enough from the main island to be independent. Few of these satellite islands are nature reserves, so in strict terms of the 2025 interim goal Stewart and Great Barrier would (for now) be excluded from the candidate islands.

Waiheke and Pitt Islands are inhabited and meeting the 2025 deadline might prove difficult because we suspect lengthy periods of community consultation would be required and even then consent is not guaranteed. For example, Pitt islanders might consider removing mice and cats, but maybe not the pigs that are seen (as on Chatham, Great Barrier, D'Urville and Arapawa Islands) as a hunting asset (e.g. Nugent et al. 1995).

Among the rodent-only islands, the kiore on Mauitaha Island are protected under an agreement with Ngatiwai who have mana whenua (traditional ownership) over the Hen and Chicken Islands and wish to retain kiore on one island 
(D. Towns, pers. comm.). Some DOC reserves with rodents, e.g. Quail, Pomona and Limestone Islands are managed by local trusts, while White Island is privately owned and managed as a private reserve. Eradicating rodents from other 'smaller' rodent-only islands would be routine (therefore not strictly a 'stretch' goal that would inform the PFNZ2050 initiative) and Motukawanui and Rakitu islands are already mooted for projects.

Auckland Island is wholly in the conservation estate. Only one of its adjacent islands (Masked Island) has mammals present, and eradicating the pigs, cats and mice would have major biodiversity benefits. One option would be to attempt eradication of all species in a single campaign, as was done with most species on Rangitoto-Motutapu Islands (Griffiths et al. 2015) by conducting an aerial brodifacoum operation aimed at the mice which would simultaneously kill most of the pigs and cats. Some pigs are likely to eat enough of the rodent baits (and perhaps poisoned mice) to receive a lethal dose, although this is not necessarily desirable as it removes baits required to put all the mice at risk. Some cats would also eat poisoned mice (and perhaps baits) and die (e.g. see Griffiths et al. 2015). Pig (Clarke 1991; Thomas \& Young 1999) and cat specific baits (Algar et al. 2011; Johnston et al. 2011) could be distributed at the same time as the rodent baits. However, whatever option is chosen it is likely from past experience that some cats and pigs would survive and would need to be killed by ground-based trapping and hunting. Alternatively, pigs or cats could be targeted one at a time as recommended in older eradication programmes when simultaneous campaigns against two or more species suffered from mutual interference (e.g. the 1970s campaigns against cats and goats on Raoul Island used different teams of hunters and dogs which confounded one another; Parkes 1984).

The interim goals are supposed to lead to a final goal to eradicate predators from New Zealand. A major constraint in achieving this is to gain the social licence to proceed. This is not simply gaining support from enthusiasts, there are plenty of those, or even a majority support from the wider populace. Eradication is 'all or nothing'. There can be no objector to the goal of eradication or to the necessary methods to achieve on both public and private land with the power to enforce their objection. Therefore, testing the water on a smaller populated island would be desirable either as a stand-alone type of island (e.g. Chatham or Pitt) or as an island with adjacent satellites (e.g. Great Barrier or Stewart). Recent proposals to eradicate all pests from Great Barrier (Ogden \& Gilbert 2011) and Stewart (Bell \& Bramley 2013) have stalled, in part because of the difficulties in getting this social acceptance to proceed.

We have considered risks of reinvasion only by swimming, but of course all the predator species may reach or reinvade any island by other means. Some predators may arrive accidentally as disembarking stowaways on vessels or when ships are wrecked. Rodents and possums that have reached islands outside their maximum swimming ranges in recent times have arrived via this process (e.g. Russell et al. 2008). Rafting on debris is likely and elsewhere has resulted in invasion of remote islands, e.g. by the ancestors of the endemic Galapagos Islands rodents across nearly $1000 \mathrm{~km}$ of ocean (Dexter et al. 2004). Other predators, e.g. cats, pigs and ferrets, are likely to require active human assistance to reach islands, but this too is still a problem requiring ongoing biosecurity actions, e.g. a single cat was seen on pest-free Whale Island in 2016 (DOC 2016a) and unknown saboteurs have threatened to release stoats on Stewart Island, whatever eradication successes are achieved.

\section{Conclusions}

The Government's interim 2025 goal to eradicate all mammalian predators from nature reserves is, in practice, limited to the Auckland Islands if only nature reserves are included. Eradicating the mice, cats and pigs from the main Auckland Island is not a trivial project but would result in major biodiversity benefits. However, by itself it would provide little support for a wider PFNZ2050 initiative. Widening the tenure criterion to include all islands with any reserved lands is required to provide 'stretch' goals. Two islands (Motukawanui and Rakitu) with rats present are already in planning stages and present no stretch in funding or techniques to achieve success. However, we argue that if the 2025 criteria are widened to include large scale, private reserves or eradications on populated islands then the 2025 goal is not trivial. Here the Government has some options. None of the private reserve islands (White, Limestone) present much stretch in eradicating the predators present. DOC could select the only uninhabited large island, Auckland Island with mice, cats and pigs, and clear it of some or all predator species. The cost would likely exceed the current Government budget allocated to the whole PFNZ2050 initiative - aerial bait for mice would cost at least \$14 million judging by past projects, and DOC has estimated costs to target cats and pigs alone would be $\$ 22$ million (DOC 2016b).

One island with mixed tenures, few predator species and a human population could be selected (e.g. Pitt Island with mice, cats and pigs) to learn how to eradicate when social consent is not a foregone condition (Glen et al. 2013). Or a large multi-island group could be selected (e.g. Stewart or Great Barrier Islands) with many pests, many stakeholders and inhabitants and test whether the wider vision of a PFNZ2050 is technically and socially feasible. Previous proposals to eradicate at least some of the mammals from inhabited islands show how difficult it can be to obtain social consent from all islanders when, for eradication, any single landowner has the potential ability to constrain the project's feasibility. In New Zealand, a proposal was made in 2006 to eradicate stoats from D'Urville Island (Brown 2006, unpubl. D'Urville Island stoat eradication a feasibility study) but it took until 2016 to gain approval from the island's residents to justify the development of an operational plan, albeit without the use of toxins (Butler \& Macalister 2016, unpubl. data). Similarly, the first proposal to eradicate ship rats and mice from Lord Howe Island (1455 ha) was made in 2001 (Saunders \& Brown 2001, unpubl. report on an assessment of the feasibility of eradicating rodents from the Lord Howe Island group). Many subsequent cost-benefit analyses, risk reviews, operational plans and government commitments (Wilkinson \& Priddel 2011) failed to convince the islanders that the project should proceed and, as of 2017 , the plan has yet to be put into operation. We conclude that unless the predators can be eradicated from at least one of the inhabited islands in Table 3 then the wider PFNZ2050 is not a vision but a mirage that will divert resources from better strategies to manage mammal pests on the main islands of New Zealand (Parkes et al. 2017).

\section{Acknowledgements}

We thank Keith Broome, Pete McClelland, Susan Timmins, Dave Towns, Gerard Hill and the Editor's referees for comments on drafts of this paper and information on the status of many islands. 


\section{References}

Algar D, Johnstone M, Hilmer SS 2011. A pilot study for the proposed eradication of feral cats on Dirk Hartog Island, Western Australia. In: Veitch CR, Clout MN, Towns DR eds. Island invasives: eradication and management. Gland, Switzerland, IUCN. Pp. 10-16.

Anderson DP, McMurtrie P, Edge K-A, Baxter PWJ, Byrom AE 2016. Inferential and forward projection modelling to evaluate options for controlling invasive mammals on islands. Ecological Applications 26: 2548-2559.

Bell P, Bramley A 2013. Eliminating predators from Stewart Island. Wellington, Department of Conservation. $23 \mathrm{p}$.

Broome K, Cox A, Golding C, Cromarty P, Bell P, McClelland P 2014. Rat eradication using aerial baiting. Current agreed best practice used in New Zealand. Version 3.0. Wellington, Department of Conservation. 23 p.

Cabinet 2016. Accelerating predator free New Zealand. CAB-16-MIN-0335. Cabinet Economic Growth and Infrastructure Committee. $4 \mathrm{p}$.

Campbell KJ, Harper G, Algar D, Hanson CC, Keitt BS, Robinson S 2011. Review of feral cat eradications on islands. In: Veitch CR, Clout MN, Towns DR eds. Island invasives: eradication and management. Gland, Switzerland, IUCN. Pp. 37-46.

Clarke CMH 1991. The acceptance of non-toxic polymer baits by feral pigs on Auckland Island. Forest Research Institute Contract Report FEW 91/20. Christchurch, Forest Research Institute. $10 \mathrm{p}$.

Clayton RI, Byrom AE, Anderson DP, Edge K-A, Gleeson D, McMurtrie P, VealeA2011. Density estimates and detection models inform stoat (Mustela erminea) eradication on Resolution Island, New Zealand. In: Veitch CR, Clout $\mathrm{MN}$, Towns DR eds. Island invasives: eradication and management. Gland, Switzerland, IUCN. Pp. 413-417.

Clout MN, Russell JC 2006. The eradication of mammals from New Zealand islands. In: Koike F, Clout MN, Kawamichi M, De Poorter M, Iwatsuki K eds. Assessment and control of biological invasion risks. Gland, Switzerland, IUCN. Pp. 127-141.

Cowan PE 1992. The eradication of introduced Australian brushtail possums, Trichosurus vulpecula, from Kapiti Island, a New Zealand nature reserve. Biological Conservation 61: 217-226.

Crouchley D 1994. Stoat control on Maud Island 1982-1993. Ecological Management 2: 39-45.

Department of Conservation 2016a. Cat seen on pest-free sanctuary Moutohorā (Whale Island). www.doc.govt.nz/ news/media-releases/2016/ (accessed 24/12/16).

Department of Conservation 2016b. Eradicating pigs and cats on the Auckland Islands. www.doc.govt.nz/our-work/ eradicating-pigs-and-cats-on-Auckland-Islands (accessed 24/12/16)

Dexter N, Dowler RC, Flanagan JP, Hart S, Revelez MA, Lee TE 2004. The influence of feral cats Felis catus on the distribution and abundance of introduced and endemic Galápagos rodents. Pacific Conservation Biology 10: 210-215.

Empson RA, Miskelly CM 1999. The risks, costs and benefits of using brodifacoum to eradicate rats from Kapiti Island, New Zealand. New Zealand Journal of Ecology 23: 241-254.

Glen AS, Atkinson R, Campbell KJ, Hagen R, Holmes ND, Keitt BS, Parkes JP, Saunders A, Sawyer J, Torres H
2103. Eradicating multiple invasive species on inhabited islands: the next big step in island restoration? Biological Invasions 15: 2589-2603.

Griffiths R, Buchanan F, Broome K, Neilson J, Brown D, Weakley M 2015. Successful eradication of invasive vertebrates on Rangitoto and Motutapu islands, New Zealand. Biological Invasions 17: 1355-1369.

Holmes ND, Campbell KJ, Keitt B, Griffiths R, Beek J, Donlan CJ, Broome K 2016. Correction: reporting costs for invasive vertebrate eradications. Biological Invasions 18: 2801-2807.

Johnstone M, Algar D, O’Donoghue M, Morris J 2011. Field efficacy of the Curiosity feral cat bait on three Australian islands. In: Veitch CR, Clout MN, Towns DR eds. Island invasives: eradication and management. Gland, Switzerland, IUCN. Pp. 182-187.

King CM ed. 2005. The handbook of New Zealand mammals. 2nd edn. Melbourne, Victoria, Oxford University Press. $610 \mathrm{p}$.

King CM, Veale A, Patty B, Hayward L 2014. Swimming capabilities of stoats and the threat to inshore sanctuaries. Biological Invasions 16: 987-995.

McCallum J 1986. Evidence of predation by kiore upon lizards from the Mokohinau islands. New Zealand Journal of Ecology 9: 83-87.

McClelland P 2001. Operational report for rat (Rattus norvegicus) eradication on the Campbell Island Nature Reserve. Invercargill, Department of Conservation. $39 \mathrm{p}$.

McMurtrie P, Edge K-A, Crouchley D, Gleeson D, Willans MJ, Veale AJ 2011. Eradication of stoats (Mustela erminea) from Secretary Island, New Zealand. In: Veitch CR, Clout MN, Towns DR eds. Island invasives: eradication and management. Gland, Switzerland, IUCN. Pp. 455-460.

Moors PJ 1985. Eradication campaigns against Rattus norvegicus on the Noises Islands, New Zealand, using brodifacoum and 1080. International Council for Bird Preservation Technical Publication 3: 143-155.

Morrison SA 2007. Reducing risk and enhancing efficiency in non-native vertebrate removal efforts on islands: a 25 year multi-taxa retrospective from Santa Cruz Island, California. In: Witmer GW, Pitt WC, Fagerstone KA eds. Managing vertebrate invasive species. Proceedings of an International Symposium. USDA/APHIS/WS, National Wildlife Research Center, Fort Collins. Pp. 398-409.

Nugent G, Parkes JP, Dawson N, Caley P 1995. Feral pigs in New Zealand as conservation pests and as potential hosts of bovine tuberculosis. Unpublished Landcare Research contract report LC9596/54. 57 p.

Ogden J, Gilbert J 2011. Running the gauntlet: advocating rat and feral cat eradication on an inhabited island Great Barrier Island, New Zealand. In: Veitch CR, Clout MN, Towns DR eds. Island invasives: eradication and management. Gland, Switzerland, IUCN. Pp. 467-471.

Parkes JP 1984. Feral goats on Raoul Island. I. Effect of control methods on their density, distribution, and productivity. New Zealand Journal of Ecology 7: 85-94.

Parkes J, Murphy E2003. Management of introduced mammals in New Zealand. New Zealand Journal of Zoology 30: 335-359.

Parkes JP, Panetta FD 2009. Eradication of invasive species: progress and emerging issues in the $21^{\text {st }}$ century. In: Clout MN, Williams PAeds. Invasive species management. New York, Oxford University Press. Pp. 47-60.

Parkes JP, Nugent G, Forsyth DM, Byrom AE, Pech RP, 
Warburton B, Choquenot D 2017. Past, present and two potential futures for managing New Zealand's mammalian pests. New Zealand Journal of Ecology 41: 151-161.

Prada D, Veale A, Duckworth J, Murphy E, Treadgold S, Howitt R. Hunter S, Gleeson D 2014. Unwelcome visitors: employing forensic methodologies to inform the stoat (Mustela erminea) incursion response plan on Kapiti Island. New Zealand Journal of Zoology 41: 1-9.

Robinson SA, Copson GR 2014. Eradication of cats (Felis catus) from subantarctic Macquarie Island. Ecological Management \& Restoration 15: 34-40.

Russell JC, Towns DR, Clout MN 2008. Review of rat invasion biology. Implications for island biosecurity. Science for Conservation 286. Wellington, Department of Conservation. 53 p.

Taylor RH, Tilley JAV 1984. Stoats (Mustela erminea) on Adele and Fisherman Islands, Abel Tasman National Park, and other offshore islands in New Zealand. New Zealand Journal of Ecology 7: 139-145.

Thomas M, Young N 1999. Preliminary trial of a water-resistant bait for feral pig control. Science for Conservation 127: 49-55.

Editorial board member: Hannah Buckley

Received 28 November 2016; accepted 2 March 2017
Towns DR, West CJ, Broome KG 2012. Purposes, outcomes and challenges of eradicating invasive mammals from New Zealand islands: an historical perspective. Wildlife Research 40: 94-107.

Veale AJ, Clout MN, Gleeson DM 2012. Genetic population assignment reveals a long-distance incursion to an island by a stoat (Mustela erminea). Biological Invasions 14: 735-742.

Veale AJ, Edge K-A, McMurtrie P, Fewster R, Clout MN, Gleeson DM 2013. Calculating survival and reinvasion rates using genetic methods during an intensive control operation: stoats (Mustela erminea) on Secretary Island. Molecular Ecology 22: 5071-5083.

Whitaker AH 1974. Report on a visit to the Mokohinau Islands, Hauraki Gulf, 20 November to 4 December 1973. Unpublished report to the Department of Lands and Survey, Wellington.

Wilkinson IS, Priddel D 2011. Rodent eradication on Lord Howe Island: challenges posed by people, livestock, and threatened endemics. In: Veitch CR, Clout MN, Towns DR eds. Island invasives: eradication and management. Gland, Switzerland, IUCN. Pp. 508-514. 